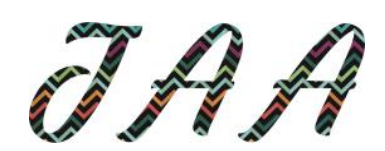

Vol. 5, No. 1, Oktober 2020

\title{
THE IMPACT OF ESG PERFORMANCE TO FIRM PERFORMANCE AND MARKET VALUE
}

\author{
David Junius ${ }^{1)}$ \\ Universitas Prasetiya Mulya \\ david.junius@student.pmsbe.ac.id \\ Adriel Adisurjo ${ }^{2)}$ \\ Universitas Prasetiya Mulya \\ adriel.adisurjo@student.pmsbe.ac.id \\ Y. Arief Rijanto ${ }^{3}$ \\ Universitas Prasetiya Mulya \\ arief.rijanto@pmbs.ac.id \\ Yang Elvi Adelina4) \\ Universitas Prasetiya Mulya \\ yang.elvi@pmbs.ac.id
}

\begin{abstract}
This research aims to investigate the impact of ESG performance on firm performance and market value. Total samples used are 271 listed companies (1355 firm-years observations) in five years period (20132017), which consisted of four ASEAN countries (Indonesia, Malaysia, Singapore, and Thailand). This study is analyzed using multiple regression analyses with the random-effect model and descriptive statistic. The independent variable is ESG Score; the dependent variables are three performance indicators (Return on Assets, Return on Equity, and Tobin's Q) and Price-Earnings ratio; the control variables are firm size, firm's age, financial leverage, and industry. This research contributes to broadening the scope of the literature review regardings ESG performance by analyzing it on developing countries and also by using rarely used dependent variables, market value. The finding in this research is there is no significant influence from ESG Score to Firm Performance and Market Value because ESG Score is not yet a part of firm performance measurement. This research is limited in conducting lag effect research with the lag period of only one year, and also the number of companies that already have ESG scores is limited.
\end{abstract}

Keywords: ESG, Operational Performance, Financial

Performance, Market Value, Sustainability

Abstrak 
Penelitian ini bertujuan untuk meneliti pengaruh kinerja ESG terhadap kinerja perusahaan dan nilai pasar. Jumlah sampel adalah sebanyak 271 perusahaan terdaftar (1355 observasi) dalam periode 2013-2017 yang berasal dari empat negara ASEAN (Indonesia, Malaysia, Singapura, dan Thailand). Penelitian ini dianalisis menggunakan regresi berganda dengan model random-effect dan statistik deskriptif. Variabel independen yang digunakan adalah nilai ESG; variabel dependen yang digunakan adalah tiga indikator kinerja perusahaan (return on assets, return on equity, dan tobin's q) dan price-earnings ratio; variabel kontrol adalah ukuran perusahaan, umur perusahaan, financial leverage, dan sektor industri. Penelitian ini berkontribusi dengan menambah literatur mengenai pengaruh kinerja ESG di negara ASEAN dan menambahkan variabel dependen yang sebelumnya belum banyak digunakan yaitu nilai pasar. Hasil penelitian menunjukan bahwa kinerja ESG tidak memiliki pengaruh terhadap kinerja perusahaan ataupun nilai pasar yang diindikasikan karena nilai ESG belum menjadi bagian dari kinerja perusahaan. Penelitian ini terbatas pada analisa lag yang hanya menggunakan satu tahun perbedaan dan jumlah perusahaan sampel yang sudah memiliki nilai ESG masih terbatas.

\section{Kata kunci: ESG, Kinerja Operasional, Kinerja Keuangan, Nilai Pasar, Keberlanjutan}

\section{INTRODUCTION}

Nowadays, corporations and entrepreneurs are expected to not only conduct their daily business operations properly but also to pay attention to how their businesses affect the surrounding environment. This is in line with the concept of sustainability which has three dimensions: people, profit and planet, also widely known as the triple bottom line (Elkington 1997 in Caesaria and Basuki 2017). According to Nilsson, Griggs, and Visbeck (2016), Sustainable Development Goals (SDG) are a set of objectives related to sustainable development that is composed by The United Nations (UN) in order to face the current concerning global issues. The SDGs are aimed at every organization and individuals worldwide and expected to be achieved effectively by 2030 . The SDGs required corporates and entrepreneurs to achieve the 17 sustainable development goals, which are reported as the sustainability report for some corporates and countries.

Sustainable development and sustainability reporting have been deemed as important aspects of the economy. This is proven by how the rising number of researches about the impact of ESG Performance on 


\section{$D A A$}

Vol. 5, No. 1, Oktober 2020

other aspects, especially about how it affects firm performance with the intention of encouraging companies all around the world to start complying to sustainability reporting.

This research aims to prove the positive impact of ESG Performance on Firm Performance and Market Value. The proxies used on ESG Performance and Firm Performance are conducted based on the study by Buallay (2018). The ESG Performance is measured by Bloomberg's ESG score, meanwhile, the firm performance is separated into three indicators. Those are operational performance measured by return on assets, financial performance measured by return on equity and market performance measured by Tobin's Q. Moreover, this research also uses Market Value proxied by Price-Earnings ratio.

Subsequently, four developing ASEAN (Association of Southeast Asian Nations) countries are used as samples: Indonesia, Malaysia, Thailand, and Singapore. These countries are selected referring to the previous study by Tarmuji, Maelah, and Tarmuji (2016) who stated that normally, the researches on ESG are conducted in developed countries, thus more researches are needed regardings ESG Performance in developing countries. Hence these four countries are used as samples to study if there are any differences in ESG Performance if the research is conducted in developing countries. Additionally, the selection of the developing countries is expected to widen the scope of literature.

The main issue in this research is that although sustainability reporting importance has risen globally, including Indonesia who will soon stipulate sustainability reporting as a mandatory report for the reporting period of 2020. However, the number of companies that have voluntarily conducted a sustainability report is still fairly low. This is may due to the assumption that there is no impact of conducting a sustainability report of the companies' operational activities on the performance and market value.

The target of this research is to analyze the impact of ESG Performance on firm performance and market value on some developing ASEAN countries. The contributions of this research are to broaden the scope of a literature review regarding ESG Performance, adding the variable of Market Value which is rarely used as a dependent variable, and to show the differences of the impact of ESG Performance between developing and developed countries. The systematic presentation of this study begins with an introduction to the basis of the study, followed by the literature review and hypotheses containing the supporting theories and the development of the proposed hypothesis. Subsequently, the research method used will be explained, including the method of data processing. Finally, this study will be finished by a discussion of the results and conclusions. 


\section{LITERATURE REVIEW AND HYPOTHESES DEVELOPMENT Stakeholder Theory}

The development of the sustainability report and ESG are originated from the idea of stakeholder theory by R. Edward Freeman in 1984 (Velte 2017). It stated that shareholders are not the only important entity that should be concerned about, but there are also other stakeholders such as employees, communities, citizens, etc. That statement is supported by the study of Donaldson and Preston (1995) in Tarigan and Semuel (2014) who stated that companies are also responsible for other entities besides the shareholders. The entities referred to as stakeholders according to Freeman (1984) in Velte (2017) are employees, customers, suppliers, financiers, communities, government, political parties, trade associations, and sometimes competitors.

\section{Legitimacy Theory}

In legitimacy theory, there exists a "social contract" that stimulates every action done by companies to be socially accepted by external parties or in other words, "legitimate" the companies' actions (Caesaria and Basuki 2017). Moreover, "social contract" by Ghozali and Chariri (2017) in Manisa and Defung (2017) is defined as something that binds the companies to the society where the companies are operating and using the economic resources. This "social contract" drives the companies to engage in sustainable development activities as public interest is rising regarding the sustainability business. By fulfilling the expectation, stakeholders will have a positive image of the company as they succeed in operating according to the extant norms and expectations in society and the environment (Deegan 2004 in Tarigan and Semuel 2014).

\section{Signaling Theory}

The fundamental concept of legitimacy theory is in line with the signaling theory. It suggests that one of the main goals of companies is to deliver a "signal" to external parties regardings the goodwill of the companies. This goodwill is usually shown by disclosing more information especially ones related to companies' sustainable development (Caesaria and Basuki 2017). According to Ross (1977), companies also tend to disclose information to external parties due to information asymmetry between them and external parties, thus placing external parties such as investors and creditors in a less knowledgable position about companies' prospects. The lack of information may also affect external parties to defend themselves by value the companies less. 


\section{Sustainability Reporting Tools}

The rise of sustainability reporting by companies can be shown by the development of scoring tools over the last two decades (Siew 2015). Out of three forms of SRT (framework, standards, and rating), this research utilized the ESG rating from Bloomberg, where the generated score is in accordance with the framework from GRI and standard from SASB (Sustainability Accountings Standard Board) (Siew 2015). The scope of Bloomberg ESG Scoring has covered almost all countries around the world and the number keeps rising annually for approximately 11 to $12 \%$ (Suzuki and Levy 2010 in Siew 2015). Ditto as other rating agencies, Bloomberg ESG Score is in the range of 0 to 100 within four main categories: Environmental Disclosure Score, Social Disclosure Score, Governance Disclosure Score and an overall average of the three aforementioned categories-ESG Disclosure Score (Suzuki and Levy 2010 in Siew 2015). The weighted scoring is executed differently for each industry (Eccles, Krzus, and Serafeim 2011 in Siew 2015).

\section{Hypotheses Development}

The first relationship this research seeks to unveil is if ESG Performance positively affects firm performance, thus high ESG Score will result in high firm performance. The first hypothesis is divided into three sub-hypotheses as the measurement is also divided into three: operational performance, financial performance, and market performance.

Operational performance measured by ROA is related to ESG Performance explained by the disclosure of sustainability report is seen as part of companies' goodwill, hence better reporting disclosure will give higher ESG Score that will rise companies' ROA (Buallay 2018).Therefore, the first hypothesis is:

\section{$H_{1 a}$ : ESG Performance positively affected the Operational Performance}

Regarding the Financial Performance, Buallay (2018) stated that sustainable development activities are expected to draw more demand for products and services that will promote companies' growth and lower business risk. Another study that proves a positive relationship between ESG Performance and Financial Performance is by Margolis, Elfenbein, and Walsh (2007) in Buallay (2018). Hence, the second hypothesis is:

\section{$H_{1}$ b: ESG Performance positively affected the Financial Performance}

Lastly, the research from Barth, Cahan, Chen, and Venter (2016) in Buallay (2018) shows a result of a positive relationship between ESG Performance and Market Performance. This can be indicated from the rise in cash flow gained by sustainable development activities done by the 
company through CSR or sustainability reports, thus generated higher market value. Other studies that found similar results are by Velte (2017), Wagner (2010), and Tarigan and Semuel (2014) .Ergo, the third hypothesis is:

\section{$\mathrm{H}_{1} \mathrm{C}$ : ESG Performance positively affected the Market Performance}

The majority of previous studies about the impact of ESG Performance only associate it to performance, meanwhile, there is another factor that can be observed further such as Market Value. This is supported by the research from Banerjee et al. (2009) who studied the impact of corporate governance on the Price-Earning Ratio (PER) as a measurement of Market Value. The result showed that companies with higher corporate governance tend to have higher PER, indicating a positive relationship between the two variables. PER is affected by the company's reputation (Little and Little 2000) which is linked to the statement by Clarkson, et al (2008) in Velte (2017) that the company's reputation can be boost by higher ESG Score, thereupon showing a positive relationship between the two variables. Therefore, the fourth hypothesis is:

\section{$\mathrm{H}_{2}$ : There is a positive relationship between ESG Performance and Market Value}

\section{Framework}

This study employs one independent variable, four dependent variables, and four control variables. Below is the framework for this study:

\section{Figure 1. Research Framework}

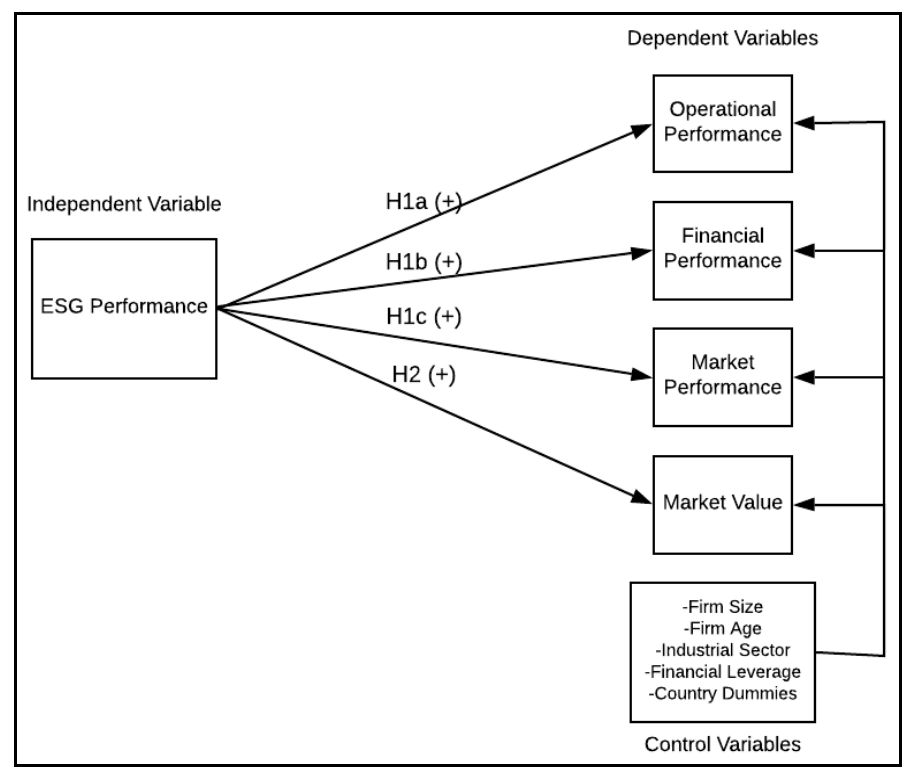




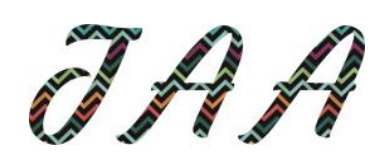

Vol. 5, No. 1, Oktober 2020

\section{RESEARCH METHOD}

This research uses panel data which is a combination of time series and cross-section data. According to Gujarati and Porter (2009), data are time series if the variables are in a set of times, whilst data are crosssection if there are many subjects but are at the same point in time.

\section{Sample and Population}

Table 1. Data Selection

\begin{tabular}{ccc}
\hline Description & Sample & Observation \\
\hline $\begin{array}{c}\text { ASEAN Countries listed in } \\
\text { Bloomberg ESG Index }\end{array}$ & 290 companies & 1450 observations \\
\hline $\begin{array}{c}\text { Companies with missing } \\
\text { information }\end{array}$ & (19 companies) & (95 observations) \\
\hline Final Sample & $\mathbf{2 7 1}$ companies & $\begin{array}{c}\mathbf{1 3 5 5} \\
\text { observations }\end{array}$ \\
\hline
\end{tabular}

As depicted in Table 1, the data used in this research are secondary as they are collected from financial statements and scoring from Bloomberg Terminal. Samples used are public companies listed in stock exchange from four ASEAN countries: Bursa Efek Indonesia (Indonesia); Bursa Malaysia (Malaysia); Singapore Exchange Limited (Singapura); and Stock Exchange of Thailand (Thailand) for the period of 2013 to 2017.

The four countries are selected as samples following the research by Tarmuji, Maelah, and Tarmuji (2016). It stated that the majority of ESG Performance-based researches is conducted in developed countries, hence the aforementioned study tested 35 and 45 listed companies from Malaysia and Singapore respectively as samples in their research. This research intends to follow the same perspective, howbeit the scope is widened to four developing ASEAN countries. This research ends up with only those four countries because those are the only ASEAN member listed countries in Bloomberg ESG Index. Therefore, the final sample for this study consists of 271 companies or 1355 firm-year observations.

The variables used in this study are divided into three, namely the independent variable or the binding variable, the dependent variable or the independent variable and the control variable. The following table summarizes all the variables used along with the proxies, formulas and variable references: 
David Junius, dkk: The Impact Of ESG Permormance To Firm Performance .....

Table 2. Variables Operationalization

\begin{tabular}{|c|c|c|c|}
\hline Variable & Proxy & Formula & Reference \\
\hline \multicolumn{4}{|c|}{ Independent Variable } \\
\hline $\begin{array}{c}\text { ESG } \\
\text { Performance }\end{array}$ & $\begin{array}{l}\text { ESG Score } \\
\text { (ESG) }\end{array}$ & $\begin{array}{l}\text { Economic + Social } \\
+ \text { Governance }\end{array}$ & Buallay (2018) \\
\hline \multicolumn{4}{|c|}{ Dependent Variables } \\
\hline $\begin{array}{l}\text { Operational } \\
\text { Performance }\end{array}$ & $\begin{array}{l}\text { Return on } \\
\text { Assets } \\
\text { (ROA) }\end{array}$ & $\frac{\text { Net Income }}{\text { Total Assets }}$ & $\begin{array}{c}\text { Buallay (2018), Velte } \\
\text { (2017), Griffin and Mahon } \\
\text { (1997) }\end{array}$ \\
\hline \multirow{2}{*}{$\begin{array}{c}\text { Financial } \\
\text { Performance }\end{array}$} & \multirow{2}{*}{$\begin{array}{l}\text { Return on } \\
\text { Equity } \\
\text { (ROE) }\end{array}$} & Net Income & \multirow{2}{*}{$\begin{array}{c}\text { Buallay (2018), Griffin and } \\
\text { Mahon (1997) }\end{array}$} \\
\hline & & Shareholders Equity & \\
\hline $\begin{array}{c}\text { Market } \\
\text { Performance }\end{array}$ & $\begin{array}{l}\text { Tobin's Q } \\
\text { (TQ) }\end{array}$ & $\frac{\text { Total Market Value }}{\text { Total Asset Value }}$ & $\begin{array}{c}\text { Buallay (2018), Velte } \\
\text { (2017), Griffin and Mahon } \\
\text { (1997) }\end{array}$ \\
\hline Market Value & $\begin{array}{c}\text { Price- } \\
\text { Earnings } \\
\text { Ratio (PER) }\end{array}$ & $\frac{\text { Price per Share }}{\text { Earnings per Share }}$ & $\begin{array}{c}\text { Banerjee et al. (2009), } \\
\text { Daszyńska-Żygadlo, } \\
\text { Słoński, and Zawadzki } \\
\text { (2016) }\end{array}$ \\
\hline \multicolumn{4}{|c|}{ Control Variables } \\
\hline Firm Size & $\begin{array}{c}\text { Total Assets } \\
\text { (SIZE) }\end{array}$ & Log of Total Assets & $\begin{array}{c}\text { Velte (2017), López, Garcia, } \\
\text { and Rodriguez (2007), } \\
\text { Buallay (2018), Wagner } \\
\text { (2010) }\end{array}$ \\
\hline $\begin{array}{l}\text { Financial } \\
\text { Leverage }\end{array}$ & $\begin{array}{c}\text { Debt to } \\
\text { Assets Ratio }\end{array}$ & $\frac{\text { Total Debt }}{\text { Total Assets }}$ & $\begin{array}{c}\text { Bai et al. (2004), Kao et al. } \\
\text { (2018) }\end{array}$ \\
\hline Firm Age & $\begin{array}{l}\text { Firm's Age } \\
\text { (LOGAGE) }\end{array}$ & $\begin{array}{c}\text { Company's age } \\
\text { since it's established } \\
\text { (in year) }\end{array}$ & $\begin{array}{c}\text { Buallay (2018), Wagner } \\
\text { (2010) }\end{array}$ \\
\hline
\end{tabular}




\section{JAA}

Vol. 5, No. 1, Oktober 2020

\begin{tabular}{|c|c|c|c|}
\hline Variable & Proxy & Formula & Reference \\
\hline Industry Sector & $\begin{array}{c}\text { Industrial } \\
\text { Dummy }\end{array}$ & $\begin{array}{c}1 \text { for financial and 0 } \\
\text { for non-financial }\end{array}$ & $\begin{array}{c}\text { Velte (2017), Wagner } \\
(2010) \text {, Buallay (2018), } \\
\text { López, Garcia, and } \\
\text { Rodriguez (2007) }\end{array}$ \\
\hline Country & $\begin{array}{c}\text { Country } \\
\text { Dummy }\end{array}$ & $\begin{array}{c}1 \text { for relevant } \\
\text { country and 0 for } \\
\text { other }\end{array}$ & \\
\hline
\end{tabular}

(Source: Processed Data)

The independent variable is ESG Performance measured using ESG Score from Bloomberg, and the purpose of the study is to examine whether ESG Performance has a positive effect on company performance and market value. The company performance is divided into three indicators namely operational performance measured by ROA, financial performance measured by $\mathrm{ROE}$, and market performance measured by TQ. Meanwhile, market value is measured using PER.

Additionally, few control variables are used to strengthen this study's results. The control variables used are the size of the company measured by the number of assets, the age of the company measured by calculating how long the company has been established, the financial leverage measured by debt to total assets ratio, and a dummy variable to distinguish companies that are included in the financial and non-financial industries.

\section{Descriptive Statistical Results}

\section{RESULT AND DISCUSSIONS}

Statistic descriptive test will show the results of mean, maximum and minimum, and standard deviation value of the data. Below are the results of this study's descriptive statistical results:

Table 3. Descriptive Statistics

\begin{tabular}{ccccc}
\hline Variabel & Mean & Min & Max & $\begin{array}{c}\text { Std. } \\
\text { Dev }\end{array}$ \\
\hline ESG & 26,1794 & 5,7851 & 69,0083 & 13,6607 \\
\hline ROA_w & 6,3777 & $-41,2196$ & 73,0622 & 8,5804 \\
\hline ROE_w & 16,3481 & $-151,8487$ & 492,5373 & 32,7045 \\
\hline
\end{tabular}


David Junius, dkk: The Impact Of ESG Permormance To Firm Performance .....

\begin{tabular}{ccccc}
\hline TQ_w & 1,9290 & 0,3328 & 23,2858 & 2,0152 \\
\hline PER_w & 28,7313 & 0,1539 & 2.270 & 87,3570 \\
\hline SIZE & 11,0954 & 0 & 20,8432 & 3,7826 \\
\hline LEV & 25,4599 & 0 & 92,0728 & 16,8777 \\
\hline LOGAGE & 1,5108 & 0 & 2,3365 & 0,3065 \\
\hline
\end{tabular}

Table 3 depicts the descriptive statistic of all variables excluding dummy. The ESG variable is the Bloomberg ESG Score of the sample companies and has a range of values from 0 to 100 . The average ESG variable, which is only 26,1794 , reflects that there are still very few companies in the four sample countries that have conducted sustainability reports, and it can also be assumed that sustainable development or CSR activities carried out by the sample companies are not as intensive or as expanding as companies in the developed countries in Europe.

Some variables show the range between the maximum and the minimum value that is very high, for example, the ROE variable. ROE has a minimum value of $-151.8487 \%$ which is the data of Ezion Holdings Ltd in 2017 and the maximum value is $492,5373 \%$. Another variable, the PER has a maximum value of 2270 , which is the value of PER by Thai Airways International PCL in 2016. The PER maximum value differed a lot from the minimum, 0.1539, which is the PER value of PT Darma Henwa Tbk. Meanwhile, good average PER should be between 20-25 times of income. Moreover, several variables show zero value, such as SIZE and LEV, which indicate that several companies during the research period may be undergoing some problems, thus may indicate unhealthy financial condition.

\section{Classical Assumption Test}

Data used in this research are verified using classical assumption tests namely: normality, multicorrelation, autocorrelation, and heteroscedasticity. Heteroscedasticity test and autocorrelation test show the result of Prob > chi2 and Prob > F exceeding 0,05 which means that $\mathrm{HO}$ is rejected and $\mathrm{H} 1$ is accepted, there are problems regarding heteroscedasticity and autocorrelation. Meanwhile, a multicorrelation test shows that every variable is not correlated to one another, therefore there is no problem in multicorrelation. Lastly, the normality test by inspecting the skewness and kurtosis value from every variable show the result that all variables are normally distributed. 


\section{$D A A$}

Vol. 5, No. 1, Oktober 2020

Goodness of Fit Test

As classical assumption test results show problems in heteroscedasticity and autocorrelation. However, a treatment on it will alter the data, thus this research will continue to proceed using the random effect (RE) regression model without doing the goodness of fit or model selection test beforehand. This is done by following the model used by previous study from Buallay (2018) as reference and due to the statement by Nachrowi and Usman (2006) that this research fulfills the requirements of $\mathrm{RE}$ model, which is that the number of $\mathrm{N}$ (individual) is greater than T (time) with 217 individuals and 5 years research period.

Hypotheses Test and Discussions

Table 4. Hypothesis Test Result

\begin{tabular}{|c|c|c|c|c|}
\hline \multirow{2}{*}{ Variables } & $\begin{array}{l}\text { Model } 1 \text { - } \\
\text { ROA }\end{array}$ & $\begin{array}{c}\text { Model } 2- \\
\text { ROE }\end{array}$ & $\begin{array}{c}\text { Model } 3- \\
\text { TQ }\end{array}$ & $\begin{array}{l}\text { Model } 4 \text { - } \\
\text { PER }\end{array}$ \\
\hline & Coef. & Coef. & Coef. & Coef. \\
\hline \multirow{2}{*}{ ESG } & $-0,0100$ & $-0,0176$ & $-0,0021$ & $-0,0327$ \\
\hline & $(0,503)$ & $(0,661)$ & $(0,301)$ & $(0,413)$ \\
\hline \multirow{2}{*}{ SIZE } & $-0,2682$ & $-0,1796$ & $-0,053$ & 0,1492 \\
\hline & $(0,062)$ & $(0,603)$ & $(0,030 *)$ & $(0,611)$ \\
\hline \multirow{2}{*}{ LOGAGE } & $-3,2150$ & $-5,0145$ & $-0,5012$ & $-0,759$ \\
\hline & $\left(0,005^{* *}\right)$ & $(0,063)$ & $\left(0,018^{*}\right)$ & $(0,733)$ \\
\hline \multirow{2}{*}{ IND } & $-3,4864$ & $-2,5457$ & $-0,8175$ & $-9,278$ \\
\hline & $\left(0,000^{* * *}\right)$ & $(0,224)$ & $(0,000 * * *)$ & $(0,000 * * *)$ \\
\hline \multirow{2}{*}{ LEV } & $-0,1704$ & $-0,3548$ & $-0,0157$ & 0,0226 \\
\hline & $(0,000 * * *)$ & $(0,000 * * *)$ & $(0,000 * * *)$ & $(0,513)$ \\
\hline \multirow{2}{*}{ CNTRY1 } & $-0,9585$ & $-5,0037$ & 0,1263 & 1,664 \\
\hline & $(0,456)$ & $(0,092)$ & $(0,629)$ & $(0,494)$ \\
\hline \multirow{2}{*}{ CNTRY2 } & $-1,4652$ & 0,1190 & $-0,3347$ & $-1,2592$ \\
\hline & $(0,292)$ & $(0,971)$ & $(0,221)$ & $(0,636)$ \\
\hline \multirow{2}{*}{ CNTRY3 } & $-2,2014$ & $-3,6261$ & $-0,9260$ & $-4,2053$ \\
\hline & $(0,151)$ & $(0,309)$ & $(0,002 * *)$ & $(0,153)$ \\
\hline _cons & 20,3984 & 33,4328 & 4,2045 & 25,1373 \\
\hline
\end{tabular}




\begin{tabular}{|c|c|c|c|c|}
\hline Variables & $\begin{array}{l}\text { Model } 1 \text { - } \\
\text { ROA }\end{array}$ & $\begin{array}{l}\text { Model } 2- \\
\text { ROE }\end{array}$ & $\begin{array}{c}\text { Model } 3- \\
\text { TQ }\end{array}$ & $\begin{array}{l}\text { Model } 4 \text { - } \\
\text { PER }\end{array}$ \\
\hline & Coef. & Coef. & Coef. & Coef. \\
\hline & $(0,000 * * *)$ & $(0,000 * * *)$ & $(0,000 * * *)$ & $(0,000 * * *)$ \\
\hline Prob > chi2 & 0,0000 & 0,0000 & 0,0000 & 0,0000 \\
\hline $\begin{array}{l}\text { Adjusted } R- \\
\text { squared }\end{array}$ & 0,1290 & 0,0337 & 0,1492 & 0,0864 \\
\hline
\end{tabular}

This research has four models which are Operational Performance, Financial Performance, Market Performance, and Market Value. ESG shows an insignificant influence on every measurement of firm performance and market value. This result can be attributed to the selection of developing ASEAN countries as samples. This result is in contrast to the previous studies that used the developed countries from Europe and others as samples.

The first model's regression shows insignificant influence as its $p$ value is exceeding the normal threshold with a value of 0,793 . Thus, the regression result shows that $\mathrm{H} 1 \mathrm{a}$ is rejected. This result is supported by the study from Ahmed, Islam, and Hasan (2012) who analyzed the relationship between CSR and Financial Performance indicators such as Operational Performance (ROA) and also obtain an insignificant relationship between the two aforementioned with Bangladesh as sample country. This result shows that although companies disclose their sustainable development activities, there is no impact on their earnings from assets management. The reason behind this can be assumed due to the public's perspective that sustainable development won't bring any value addition to the companies and doesn't affect their decision in purchasing a product or service.

The regression result of the second model also shows insignificant influence yet it has the lowest coefficient of determination ( $r$-squared) amongst all model, with only $3,37 \%$, hence independent variable is not expected to fully determines dependent variable in this model, which is Financial Performance (ROE). However, regarding the regression, it still decided that $\mathrm{H} 1 \mathrm{~b}$ is rejected. This is speculated to happen due to a similar reason as in the first model, that the public doesn't see sustainable development as an added value to the companies and doesn't affect their decision in investing. This result is supported by the study of Tarmuji, Maelah, and Tarmuji (2016) that showed only Corporate Governance Disclosure has a significant impact on economic performance, which one 


\section{$D A A$}

Vol. 5, No. 1, Oktober 2020

of the measurements is ROE. However, other dimensions of the ESG show no significant influence. Also, their research used Singapore and Malaysia as samples thus that is more similar to this research.

The third model regression shows insignificant influence, the same result as in two previous models. Thus, that result indicates that $\mathrm{H} 1 \mathrm{c}$ is rejected. This is also implied that in the countries used as samples, market reaction is not influenced by whether companies participate in sustainable development. It is speculated that the information and knowledge regarding sustainable development and sustainability reporting have not yet developed in the sample countries thus are not included as factors that affect their market decisions. This result is not in line with signaling theory as the signal delivered by companies in the form of disclosure of their sustainable development activities and sustainability report does not yield a positive return from the public. Previous research from Velte (2017) supports this result, who also used ESG Score as an indicator of ESG Performance and Tobin's Q as an indicator of market-based performance, and shows an insignificant relationship.

The last model regression shows similar results as all previous models. Thus the last hypothesis is also rejected. This result shows that market value is not affected by companies' ESG performance. As in the market value model, it is assumed that sustainable development activities are not yet generally known by the public and is not part of their consideration in the market decision. This result also contradicts the signaling theory, which stated that the information regardings companies' sustainable development activities will be perceived by the public as a signal for a positive act. However, in reality, it does not yield any return to the companies. A previous study by Ahmed, Islam, and Hasan (2012) who used PER as an indicator of Market Value supports this result.

Finally, there are eight control variables used in this research namely: SIZE, LEV, IND, LOGAGE, CNTRY1, CNTRY2, and CNTRY3. LEV shows a significant influence on Operational Performance, Financial Performance, and Market Performance. Whilst, IND depicts a significant aftereffect on Operational Performance, Financial Performance, and Market Value. Other control variables that also show significant influence are SIZE at $10 \%$ to Market Performance, LOGAGE at 5\% to Operational Performance, and $10 \%$ to Market Performance. 
Table 5. Regression t-1

\begin{tabular}{|c|c|c|c|c|}
\hline \multirow{2}{*}{ Variables } & $\begin{array}{l}\text { Model } 1 \text { - } \\
\text { ROA }\end{array}$ & $\begin{array}{l}\text { Model } 2 \text { - } \\
\text { ROE }\end{array}$ & $\begin{array}{l}\text { Model } 3 \text { - } \\
\text { TQ }\end{array}$ & $\begin{array}{l}\text { Model } 4 \text { - } \\
\text { PER }\end{array}$ \\
\hline & Coef. & Coef. & Coef. & Coef. \\
\hline \multirow{2}{*}{ ESG } & $-0,004$ & 0,0033 & 0,0006 & $-0,0515$ \\
\hline & $(0,793)$ & $(0,925)$ & $(0,768)$ & $(0,142)$ \\
\hline \multirow{2}{*}{ SIZE } & $-0,1851$ & $-0,4969$ & $-0,0218$ & 0,2977 \\
\hline & $(0,000 * * *)$ & $(0,000 * * *)$ & $(0,000 * * *)$ & $(0,003 * *)$ \\
\hline \multirow{2}{*}{ LOGAGE } & $-3,4633$ & $-3,6887$ & $-0,3041$ & $-0,8074$ \\
\hline & $(0,002 * *)$ & $(0,130)$ & $(0,141)$ & $(0,666)$ \\
\hline \multirow{2}{*}{ IND } & $-3,9534$ & $-1,8437$ & $-0,9322$ & $-8,6503$ \\
\hline & $(0,000 * * *)$ & $(0,331)$ & $(0,000 * * *)$ & $(0,000 * * *)$ \\
\hline \multirow{2}{*}{ LEV } & $-0,1557$ & $-0,1781$ & $-0,0208$ & 0,0332 \\
\hline & $(0,000 * * *)$ & $(0,000 * * *)$ & $(0,000 * * *)$ & $(0,270)$ \\
\hline \multirow{2}{*}{ CNTRY1 } & $-1,2133$ & $-2,4133$ & 0,0115 & 1,1161 \\
\hline & $(0,292)$ & $(0,319)$ & $(0,961)$ & $(0,540)$ \\
\hline \multirow{2}{*}{ CNTRY2 } & $-0,9623$ & $-1,8783$ & $-0,1826$ & $-1,6845$ \\
\hline & $(0,381)$ & $(0,415)$ & $(0,421)$ & $(0,332)$ \\
\hline \multirow{2}{*}{ CNTRY3 } & $-1,6482$ & $-6,2166$ & $-0,7013$ & $-4,0383$ \\
\hline & $(0,154)$ & $\left(0,011^{*}\right)$ & $(0,003 * *)$ & $(0,029 *)$ \\
\hline \multirow{2}{*}{ _cons } & 19,2855 & 32,1821 & 3,5601 & 22,5881 \\
\hline & $(0,000 * * *)$ & $(0,000 * * *)$ & $(0,000 * * *)$ & $(0,000 * * *)$ \\
\hline Prob $>\mathrm{F}$ & 0,0000 & 0,0000 & 0,0000 & 0,0000 \\
\hline $\begin{array}{l}\text { Adjusted } \\
R \text {-squared }\end{array}$ & 0,1372 & 0,0466 & 0,1269 & 0,0996 \\
\hline \multicolumn{5}{|c|}{$P$-value significant at $* * *=1 \% ; * *=5 \% ;$ dan $*=10 \%$} \\
\hline $\begin{array}{l}\text { The } s \\
\text { to } 201 \\
\mathrm{~m} \text { per }\end{array}$ & dy also conc & $\begin{array}{l}\text { ed data pro } \\
\text { the indepe }\end{array}$ & ing for the & $\begin{array}{l}\text { period from } \\
\text { influences } \\
\text { he following } \\
\text { applied for }\end{array}$ \\
\hline
\end{tabular}


the $\mathrm{t}-1$ period data using the RE regression model. There is no difference in the number of samples or observations for $\mathrm{t}-1$ period data.

Overall, shown by Table $5, \mathrm{t}-1$ test results exhibit a greater coefficient of determination compared to the results of the original period test. The regression test for the analysis of the $\mathrm{t}-1$ period showed the same results as the original period, there is no significant influence of the independent variables on the dependent variable in each model. This indicates that there is no gap time in the effect of ESG performance, or in other words, the effect of ESG performance occurred in the same year as the ESG Score was issued. However, there is a possibility that the gap time from the influence of ESG Performance is more than one year.

This research also conducts a robustness test by running a regression test for each of four countries separately and it generated the following result:

Table 6. Robustness Test

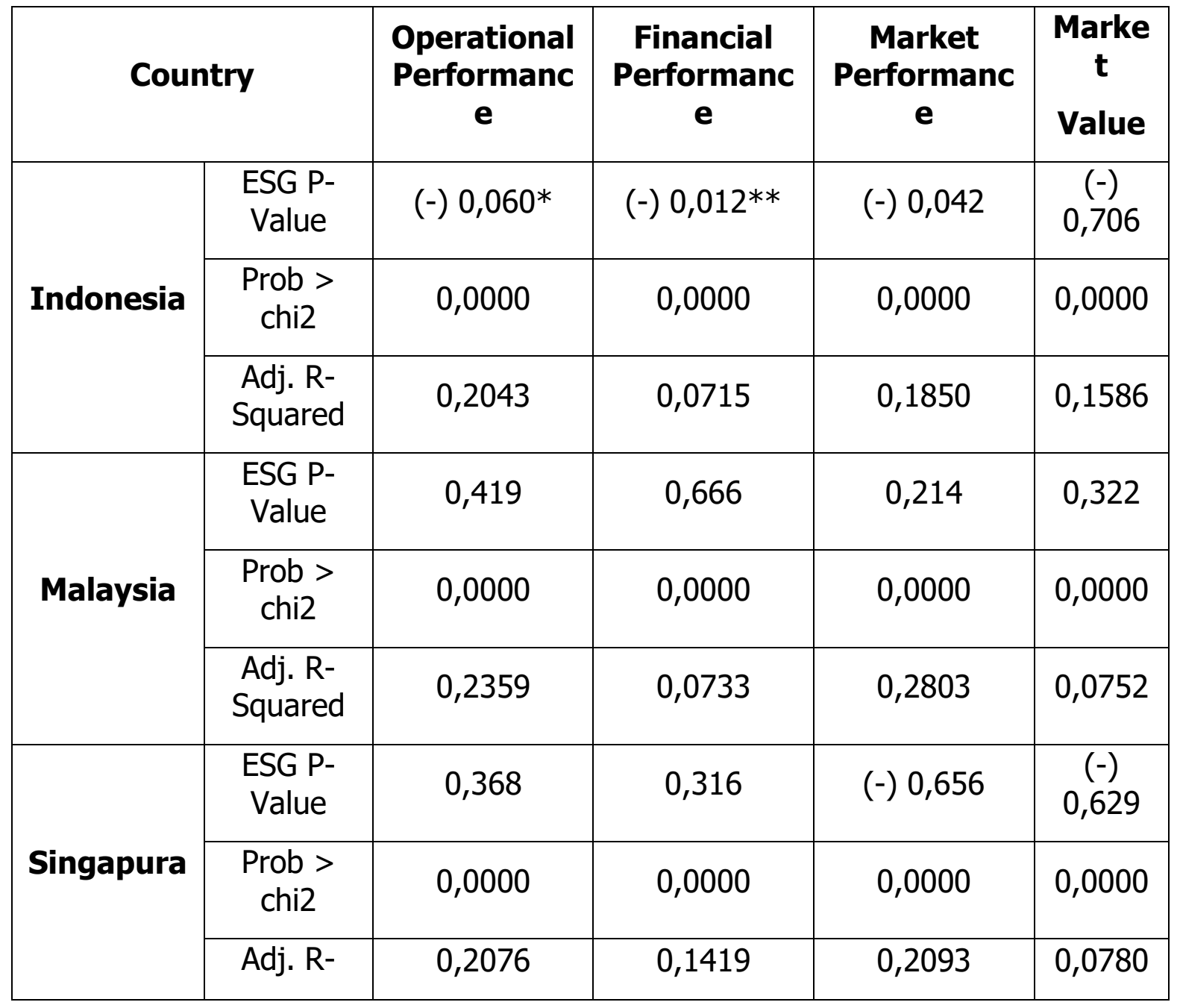


David Junius, dkk: The Impact Of ESG Permormance To Firm Performance .....

\begin{tabular}{|c|c|c|c|c|c|}
\hline \multicolumn{2}{|c|}{ Country } & $\begin{array}{c}\text { Operational } \\
\text { Performanc } \\
\text { e }\end{array}$ & $\begin{array}{c}\text { Financial } \\
\text { Performanc } \\
\text { e }\end{array}$ & $\begin{array}{c}\text { Market } \\
\text { Performanc } \\
\text { e }\end{array}$ & $\begin{array}{c}\text { Marke } \\
\text { t } \\
\text { Value }\end{array}$ \\
\hline \multirow{4}{*}{ Thailand } & Squared & & & & \\
\cline { 2 - 6 } & $\begin{array}{c}\text { ESG P- } \\
\text { Value }\end{array}$ & $(-) 0,563$ & 0,888 & $(-) 0,327$ & $\begin{array}{c}(-) \\
\text { Prob }> \\
\end{array}$ \\
\cline { 2 - 6 } & $\begin{array}{c}\text { Adj. R- } \\
\text { Squared }\end{array}$ & 0,0000 & 0,0000 & 0,0000 & 0,0000 \\
\hline
\end{tabular}

Table 6 shows the results that although all models have a good Prob> chi2 which is below 0.05 and indicates that the model is fit, howbeit, the coefficient of determination of several models such as financial performance and market values exhibit small value. This indicates that the independent variable cannot properly explain the dependent variable. The results of the ESG's p-value for each dependent variable in the entire models also showed that there is no significant relationship between the two except Indonesia, which showed a significant negative effect. The insignificant results in the regression on Malaysia, Thailand, and Singapore; and the significantly negative result in the regression on Indonesia may indicate that this happened because the information regarding the implications of the ESG Score of Malaysian companies has not been linked to their performance, so it is not a factor influencing the decision making of external parties such as investors.

The conclusion that can be drawn from the results of the separate regression of each country is that since each of the models does not show any significant influence from the ESG performance, it proves that the results of the regression test are consistent. The results of the regression per independent of the four countries also showed consistency in the effect of control variables where the variables of LEV and IND are the two control variables that showed the most significant relationship to the dependent variable. The results also show that in all four countries, financial leverage or the ability of companies to meet their obligations to use assets, the company's age, and the financial industry sector can have a significant influence on firm performance and market value. 
Table 7. Data Distribution Analysis

\begin{tabular}{cccccc}
\hline ESG & $\begin{array}{c}\text { Observatio } \\
\mathbf{n}\end{array}$ & ROA & ROE & TQ & PER \\
\hline $\begin{array}{c}1^{\text {st }} \text { Quartile } \\
\text { (ESG }>\end{array}$ & 56 & $7,58 \uparrow$ & $18,82 \downarrow$ & $2,09 \uparrow$ & $26,53 \downarrow$ \\
$53,2025)$ & & & & & \\
\hline $\begin{array}{c}2^{\text {nd }} \text { Quartile } \\
(37,3967<\text { ESG } \\
<53,2025)\end{array}$ & 228 & $7,19 \uparrow$ & $26,43 \uparrow$ & $1,98 \uparrow$ & $32,95 \uparrow$ \\
\hline $\begin{array}{c}3^{\text {rd }} \text { Quartile 3 } \\
(21,5909<\text { ESG } \\
<37,3967)\end{array}$ & 458 & $6,30 \uparrow$ & $15,81 \uparrow$ & $1,85 \downarrow$ & $25,52 \downarrow$ \\
\hline $\begin{array}{c}4^{\text {th }} \text { Quartile } \\
\text { (ESG < } \\
21,5909)\end{array}$ & 613 & 6,03 & 12,77 & 1,96 & 29,76 \\
& & & & & \\
\hline
\end{tabular}

The results of the absence of significant influence are also supported by the analysis of fluctuating data distribution analysis shown in Table 7. Data distribution analysis is conducted by dividing the independent variables namely ESG into four quartiles with sequential format from largest to smallest then interpreting the direction of distribution of dependent variable data on the independent variables. The direction of data distribution that is directly proportional between the independent variable and the dependent variable can be interpreted that the smaller the independent variable, the smaller the dependent variable (and vice versa). This is in line with the proposed hypothesis that the effect of ESG performance is positive on the dependent variable in each model.

Furthermore, it can be seen in Table 7 that the directions of the distribution of the dependent variables of $R O E, T Q$, and PER are fluctuating and not directly proportional to the independent variable. Thus, there are inconsistencies about whether the influence between the independent variable and the dependent variable is positive or negative, hence, it supports the results of the study which shows no significant effect. ROA variable shows the direction of data distribution that continues to increase every quarter, in line with the direction of data distribution in ESG Scores. However, the increase in the value of ROA in each quarter is not significant, which only ranges between 0.3 to 0.4 . Therefore, it can 
David Junius, dkk: The Impact Of ESG Permormance To Firm Performance .....

still support the results of an insignificant impact as shown in the original regression.

Table 8. Data Distribution Analysis t-1

\begin{tabular}{cccccc}
\hline ESG & Observation & ROA & ROE & TQ & PER \\
\hline $\begin{array}{c}1^{\text {st }} \text { Quartile } \\
(\text { ESG }>53,2025)\end{array}$ & 47 & $8,26 \downarrow$ & $19,54 \downarrow$ & $2,33 \uparrow$ & $22,57 \downarrow$ \\
\hline $\begin{array}{c}2^{\text {nd }} \text { Quartile } \\
\begin{array}{c}(37,3967<\text { ESG }< \\
53,2025)\end{array}\end{array}$ & 197 & $8,39 \uparrow$ & $34,49 \uparrow$ & $2,11 \uparrow$ & $24,30 \downarrow$ \\
\hline $\begin{array}{c}3^{\text {rd }} \text { Quartile } \\
(21,5909<\text { ESG }< \\
37,3967)\end{array}$ & 413 & $6,42 \downarrow$ & $16,41 \uparrow$ & $1,83 \downarrow$ & $25,93 \downarrow$ \\
\hline $\begin{array}{c}4^{\text {th }} \text { Quartile } \\
(E S G<21,5909)\end{array}$ & 698 & 6,77 & 14,54 & 2,01 & 27,02 \\
\hline
\end{tabular}

Lastly, this study also analyses the direction of data distribution in the period of $\mathrm{t}-1$ as shown in Table 8 . This analysis shares similar results to the original period data distribution, namely three variables that have fluctuating data distribution direction so that they are interpreted inconsistently whether they are in line or not with the hypothesis. However, the variable of PER's direction of distribution does not fluctuate, instead, it keeps decreasing every quartile. The PER variable is still not in line with the hypothesis, because the direction of data distribution in each quartile is consistent but contrary to the direction of ESG data distribution, whereas the ESG Score increases, the PER value decreases.

\section{CONCLUSION}

This study aims to prove that ESG performance as measured by Bloomberg's ESG Score has a positive effect on Company Performance and Market Value. The data used were mostly obtained from the Bloomberg Database for the period 2013 to 2016. There are 271 companies and 1355 observations as the final samples. The independent variables of the study are ESG Score (ESG) and the dependent variable is Firm Performance which is divided into three measurements namely Operational Performance (ROA); Financial Performance (ROE); and Market Performance (TQ) and Market Value (PER). 


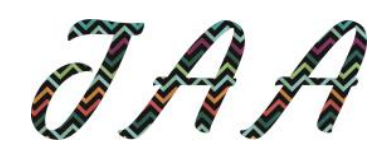

Vol. 5, No. 1, Oktober 2020

Regression test results showed that all proposed hypotheses were rejected because no significant effect was found in all four models. These results indicate that information about ESG Score or the sustainable development activities done by the companies in research countries does not increase or reduce the performance and market value of the company. This is assumed to occur because ESG research on developing countries from the ASEAN region refers to research from Tarmuji, Maelah, and Tarmuji (2016) which states that the majority of ESG-related research is conducted with a sample of developed countries in Europe. There are several studies that provide results similar to the results of this study such as from Ahmed, Islam, and Hasan (2012), Velte (2017), and Tarmuji, Maelah, and Tarmuji (2016) of which two of them also use developing countries as samples.

The study uses dummy variables to determine the effect in each country of Indonesia, Malaysia, Singapore, and Thailand respectively. It found that the country with the most influence from the ESG was Singapore, where the sustainability reports are mandatory for companies there. The study also conducted data processing for the t- 1 period from the original research period, namely from 2012 to 2016 to see whether the independent variable has a lag in its effect on the dependent variable and the same results were obtained. Ergo, there are no significant effects on the entire models.

The limitation faced in this study is that the research only analyzed the effect of the lag with a duration of only one year (t-1). The results of the $t-1$ regression analysis showed the same results as the original period regression, which indicated the possibility that the lag of ESG performance was more than one year. The study also only analyzes the effect of ESG performance using the average ESG Score, it does not discuss ESG components independently. Therefore, the effect of each component on company performance and market value is unknown and not discussed in the study.

The results of this study can be useful for several parties such as regulators or the government. This research can be a reference for the government to create benchmarks for grouping companies based on ESG performance, thus the public will be better informed. Subsequently, the research is also expected to be able to encourage companies as economic subjects to conduct sustainability reporting. Given that there is a possibility of lag from the influence of ESG performance, it may generate benefits in the future. The implication of this research for investors is to require companies to inform and integrate ESG performance indicators as part of company performance. Additionally, this research is also expected to enrich the literature review regarding the influence of ESG on firm performance and market value. 


\section{REFERENCE}

Ahmed, S. U, Z. Islam, and I. Hasan. 2012. "Corporate Social Responsibility and Financial Performance: Evidence from the Financial Sector." Journal of Organizational Management 1 (1): 14-21. https://doi.org/10.22495/cocv8i2p3.

Bai, C., Q. Liu, J. Lu, F. M. Song, and J. Zhang. 2004. "Corporate Governance and Market Valuation in China." Journal of Comparative Economics $32 \quad$ (4):

599-616.

https://doi.org/10.1016/j.jce.2004.07.002.

Banerjee, A., S. Gokarn, M. Pattanayak, and S.K. Sinha. 2009. "Corporate Governance and Market Value: Preliminary Evidence from Indian Companies." Standard \& Poor.

Buallay, A. 2018. "Is Sustainability Reporting (ESG) Associated with Performance? Evidence from the European Banking Sector." Management of Environmental Quality: An International Journal 30 (1): 98-115. https://doi.org/10.1108/MEQ-12-2017-0149.

Caesaria, A. F., and B. Basuki. 2017. "The Study of Sustainability Report Disclosure Aspects and Their Impact on the Companies' Performance." SHS Web of Conferences 34: 08001. https://doi.org/10.1051/shsconf/20173408001.

Daszyńska-Żygadlo, K., T. Słoński, and B. Zawadzki. 2016. "The Market Value of CSR Performance across Sectors." Engineering Economics 27 (2): 230-38. https://doi.org/10.5755/j01.ee.27.2.13480.

Griffin, J. J., and J. F. Mahon. 1997. "The Corporate Social Performance and Corporate Financial Performance Debate: Twenty-Five Years of Incomparable Research." Business and Society 36 (1): 5-31. https://doi.org/10.1177/000765039703600102.

Gujarati, D. N., and D. C. Porter. 2009. Basic Econometrics 5th Ed. Boston: McGraw-Hill Education.

Kao, E. H., C. Yeh, L. Wang, and H. Fung. 2018. "The Relationship between CSR and Performance: Evidence in China." Pacific Basin Finance Journal 51: 155-70. https://doi.org/10.1016/j.pacfin.2018.04.006.

Little, P. L., and B. L. Little. 2000. "Do Perceptions of Corporate Social Responsibility Contribute to Explaining Differences in Corporate PriceEarnings Ratios? A Research Note." Corporate Reputation Review 3 (2): 137-42. https://doi.org/10.1057/palgrave.crr.1540108.

López, M. V., A. Garcia, and L. Rodriguez. 2007. "Sustainable 


\section{$J A A$}

Vol. 5, No. 1, Oktober 2020

Development and Corporate Performance: A Study Based on the Dow Jones Sustainability Index." Journal of Business Ethics 75 (3): 285300. https://doi.org/10.1007/s10551-006-9253-8.

Manisa, D. E., and F. Defung. 2017. "The Influence of Disclosure of Sustainability Report on Financial Performance of Infrastructure Companies Listed on Indonesia Stock Exchange." Jurnal Ekonomi Manajemen Dan Akuntansi 19 (2): 174-87.

Nachrowi, N. D., and H. Usman. 2006. Pendekatan Populer Dan Praktis Ekonometrika Untuk Analisis Ekonomi Dan Keuangan. Jakarta: Lembaga Penerbit Fakultas Ekonomi Universitas Indonesia.

Nilsson, M., D. Griggs, and M. Visbeck. 2016. "Policy: Map the Interactions between Sustainable Development Goals." Nature 534 (7607): 32022. https://doi.org/10.1038/534320a.

Ross, S. A. 1977. "The Determination of Financial Structure: The Incentive-Signalling Approach." The Bell Journal of Economics 8 (1): 23-40.

Siew, R. Y. J. 2015. "A Review of Corporate Sustainability Reporting Tools (SRTs)." Journal of Environmental Management 164: 180-95. https://doi.org/10.1016/j.jenvman.2015.09.010.

Tarigan, J., and H. Semuel. 2014. "Pengungkapan Sustainability Report Dan Kinerja Keuangan." Jurnal Akuntansi Dan Keuangan 16 (2): 88101. https://doi.org/10.9744/jak.16.2.88-101.

Tarmuji, I., R. Maelah, and N. H. Tarmuji. 2016. "The Impact of Environmental, Social and Governance Practices (ESG) on Economic Performance: Evidence from ESG Score." International Journal of Trade, Economics and Finance 7 (3): 67-74. https://doi.org/10.18178/ijtef.2016.7.3.501.

Velte, P. 2017. "Does ESG Performance Have an Impact on Financial Performance? Evidence from Germany." Journal of Global Responsibility 8 (2): 169-78. https://doi.org/10.1108/jgr-11-20160029.

Wagner, M. 2010. "The Role of Corporate Sustainability Performance for Economic Performance: A Firm-Level Analysis of Moderation Effects." Ecological Economics 69 (7): 1553-60. https://doi.org/10.1016/j.ecolecon.2010.02.017. 